\title{
Aortic coarctation in the adult: Management of complications and coexisting arterial abnormalities with hypothermic cardiopulmonary bypass and circulatory arrest
}

Chris K. Rokkas, MD

Suzan F. Murphy, RN

Nicholas T. Kouchoukos, MD

From the Heart Center, Missouri Baptist Medical Center, St Louis, Mo.

Received for publication May 23, 2001; revisions requested Sept 18, 2001; revisions received Oct 17, 2001; accepted for publication Oct 24, 2001.

Address for reprints: Nicholas T. Kouchoukos, MD, 3009 N Ballas Rd, Suite 266-C, St Louis, MO 63131 (E-mail: NTKouch@aol.com).

J Thorac Cardiovasc Surg 2002;124:155-61

Copyright (C) 2002 by The American Association for Thoracic Surgery

0022-5223/2002 \$35.00+0 $\quad \mathbf{1 2 / 1 / 1 2 1 4 9 4}$

doi:10.1067/mtc.2002.121494
Objectives: Adult patients with aortic coarctation may have complications after childhood repair. Other adult patients have coarctation and aneurysms of the aorta and the left subclavian artery. The optimal management of such cases is not clearly established. We evaluated the role of hypothermic cardiopulmonary bypass and circulatory arrest.

Methods: Thirteen adult patients (mean age 38 years) with coarctation and coexisting abnormalities of the aorta and left subclavian artery were treated. Five patients had pseudoaneurysms develop after bypass grafting $(n=3)$ or patch angioplasty $(n=2)$. These were detected a mean of 21 years (range 13-44 years) after the initial operation. Four pseudoaneurysms were asymptomatic, and 1 had ruptured. One patient had recurrent coarctation from fibrous obliteration of a 10-mm bypass graft inserted 15 years previously. The remaining 7 patients had aneurysms of the left subclavian artery $(\mathrm{n}=5)$, aneurysms of the ascending aorta and arch $(\mathrm{n}=1)$, or stenosis of the left subclavian artery $(n=1)$ in combination with moderate or severe coarctation. Resection and interposition graft replacement of the aneurysmal or stenotic aortic segments were performed in all cases with an interval of hypothermic circulatory arrest that averaged $44 \pm 5$ minutes (range 33-54 minutes). Seven patients had interposition graft replacement of aneurysmal or stenotic left subclavian arteries.

Results: There were no in-hospital or late deaths (maximal follow-up 7 years). No patient had brain injury, paralysis, myocardial, respiratory, or renal failure. No patient has evidence of recurrent coarctation or aneurysm formation.

Conclusions: Cardiopulmonary bypass with hypothermic circulatory arrest can safely be used in the treatment of complex adult coarctation. It permits accurate delineation of the anatomy with minimal dissection, avoidance of aortic clamping and sacrifice of intercostal arteries, precise interposition graft repair, and adequate protection of vital organs.

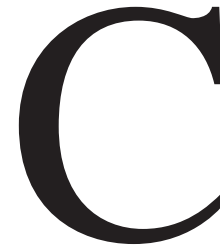

orrection of aortic coarctation usually involves the use of one of the following techniques: resection of the abnormal aortic segment and end-to-end anastomosis, ${ }^{1}$ subclavian flap aortoplasty, ${ }^{2}$ onlay graft patch aortoplasty with synthetic material or autogenous arterial wall, ${ }^{3,4}$ bypass grafting, ${ }^{5,6}$ and percutaneous balloon aortoplasty. 7,8 Some patients are seen during adulthood with recoarctation or with complications related to the surgical technique or to the prosthetic material used in the initial repair. These complications include aneurysm formation and stenosis or occlusion of bypass grafts. ${ }^{9-13}$ Other adult patients are seen with previously undiagnosed aortic coarctation and are usually treated with percutaneous balloon aortoplasty or with resection and graft interposition or end-to-end anastomosis. ${ }^{14-17} \mathrm{~A}$ 
TABLE 1. Demographic data, clinical and pathologic data, surgical procedures, and outcome

\begin{tabular}{|c|c|c|c|c|c|c|c|}
\hline Patient & $\begin{array}{l}\text { Operative } \\
\text { date }\end{array}$ & $\begin{array}{c}\text { Age } \\
\text { (y) }\end{array}$ & Sex & Previous operation & Type of disease & Procedure & Outcome \\
\hline 1 & $6 / 93$ & 41 & $\mathrm{~F}$ & $\begin{array}{l}\text { Coarctation repair with } \\
\text { bypass graft (1978) }\end{array}$ & $\begin{array}{l}\text { Pseudoaneurysm, disruption of } \\
\text { distal suture line }\end{array}$ & $\begin{array}{l}\text { Resection of coarctation and } \\
\text { replacement }\end{array}$ & $\begin{array}{l}\text { Alive and } \\
\text { well }\end{array}$ \\
\hline 2 & $7 / 93$ & 26 & M & $\begin{array}{l}\text { Coarctation repair with } \\
\text { patch aortoplasty (1980) }\end{array}$ & Pseudoaneurysm & $\begin{array}{l}\text { Resection and replacement of } \\
\text { aortic segment }\end{array}$ & $\begin{array}{l}\text { Alive and } \\
\text { well }\end{array}$ \\
\hline 3 & $3 / 94$ & 22 & $\mathrm{M}$ & $\begin{array}{l}\text { Bypass graft for hypoplasia } \\
\text { of proximal } 2 / 3 \text { of } \\
\text { descending aorta (1979) }\end{array}$ & Graft stenosis & $\begin{array}{l}\text { Resection and replacement of } \\
\text { aortic segment }\end{array}$ & $\begin{array}{l}\text { Alive and } \\
\text { well }\end{array}$ \\
\hline 4 & $3 / 94$ & 47 & $\mathrm{M}$ & None & $\begin{array}{l}\text { Coarctation and aneurysm of left } \\
\text { subclavian artery }\end{array}$ & $\begin{array}{l}\text { Resection and replacement of } \\
\text { diseased segments (aorta } \\
\text { and left subclavian) }\end{array}$ & $\begin{array}{l}\text { Alive and } \\
\text { well }\end{array}$ \\
\hline 5 & $11 / 96$ & 50 & $\mathrm{M}$ & None & $\begin{array}{l}\text { Pseudocoarctation, aneurysm of } \\
\text { proximal descending aorta and } \\
\text { both subclavian artery origins } \\
\text { (anomalous origin of right) }\end{array}$ & $\begin{array}{l}\text { Resection and replacement of } \\
\text { diseased segments, } \\
\text { reimplantation of both } \\
\text { subclavian arteries }\end{array}$ & $\begin{array}{l}\text { Alive and } \\
\text { well }\end{array}$ \\
\hline 6 & 9/97 & 27 & $\mathrm{~F}$ & $\begin{array}{l}\text { Coarctation repair with } \\
\text { bypass graft (left } \\
\text { subclavian artery to } \\
\text { aorta, 1978) }\end{array}$ & $\begin{array}{l}\text { Coarctation, pseudoaneurysms } \\
\text { (proximal and distal) }\end{array}$ & $\begin{array}{l}\text { Resection and replacement of } \\
\text { aorta and left subclavian } \\
\text { artery }\end{array}$ & $\begin{array}{l}\text { Alive and } \\
\text { well }\end{array}$ \\
\hline 7 & $5 / 98$ & 35 & $\mathrm{M}$ & None & $\begin{array}{l}\text { Pseudocoarctation, aneurysm of } \\
\text { distal aortic arch, proximal } \\
\text { descending thoracic aorta and } \\
\text { left subclavian artery }\end{array}$ & $\begin{array}{l}\text { Resection and replacement of } \\
\text { distal aortic arch, proximal } \\
\text { descending aorta, proximal } \\
\text { left subclavian artery }\end{array}$ & $\begin{array}{l}\text { Alive and } \\
\text { well }\end{array}$ \\
\hline 8 & $6 / 98$ & 22 & $\mathrm{M}$ & None & $\begin{array}{l}\text { Coarctation between left } \\
\text { subclavian and carotid arteries, } \\
\text { aneurysm of proximal } \\
\text { descending aorta, aneurysm of } \\
\text { proximal left subclavian artery }\end{array}$ & $\begin{array}{l}\text { Resection and replacement of } \\
\text { distal aortic arch, proximal } \\
\text { descending aorta, proximal } \\
\text { left subclavian artery }\end{array}$ & $\begin{array}{l}\text { Alive and } \\
\text { well }\end{array}$ \\
\hline 9 & $12 / 98$ & 71 & $\mathrm{M}$ & None & $\begin{array}{l}\text { Pseudocoarctation and aneurysm } \\
\text { of distal aortic arch and left } \\
\text { subclavian artery }\end{array}$ & $\begin{array}{l}\text { Resection and replacement of } \\
\text { distal aortic arch, proximal } \\
\text { descending aorta, proximal } \\
\text { left subclavian artery }\end{array}$ & $\begin{array}{l}\text { Alive and } \\
\text { well }\end{array}$ \\
\hline 10 & 2/99 & 20 & $\mathrm{M}$ & None & Severe coarctation & $\begin{array}{l}\text { Resection and replacement of } \\
\text { aortic segment }\end{array}$ & $\begin{array}{l}\text { Alive and } \\
\text { well }\end{array}$ \\
\hline 11 & $6 / 99$ & 37 & $\mathrm{M}$ & $\begin{array}{l}\text { Coarctation repair with } \\
\text { bypass graft (aorta to } \\
\text { aorta, 1983) }\end{array}$ & $\begin{array}{l}\text { Coarctation, pseudoaneurysms } \\
\text { (proximal and distal) }\end{array}$ & $\begin{array}{l}\text { Resection and replacement of } \\
\text { aortic segment }\end{array}$ & $\begin{array}{l}\text { Alive and } \\
\text { well }\end{array}$ \\
\hline 12 & $6 / 99$ & 63 & $\mathrm{M}$ & $\begin{array}{l}\text { Coarctation repair with } \\
\text { patch angioplasty (1955) }\end{array}$ & $\begin{array}{l}\text { Proximal pseudoaneurysm } \\
\text { compressing trachea }\end{array}$ & $\begin{array}{l}\text { Resection and replacement of } \\
\text { aortic segment }\end{array}$ & $\begin{array}{l}\text { Alive and } \\
\text { well }\end{array}$ \\
\hline 13 & $9 / 99$ & 38 & $\mathrm{M}$ & None & $\begin{array}{l}\text { Coarctation, stenosis of left } \\
\text { subclavian artery }\end{array}$ & $\begin{array}{l}\text { Resection and replacement of } \\
\text { aortic segment, } \\
\text { reimplantation of left } \\
\text { subclavian artery }\end{array}$ & $\begin{array}{l}\text { Alive and } \\
\text { well }\end{array}$ \\
\hline
\end{tabular}

$F$, Female; $M$, male.

few adult patients, however, are seen with complex forms of aortic coarctation or with coexisting abnormalities of the left subclavian artery or the aortic arch. ${ }^{18,19}$

Anatomic surgical repair in patients with complications of previous coarctation repair or in patients with complex forms of coarctation has been associated with high mortality and morbidity. ${ }^{20-23}$ The optimal management in such cases is not clearly established. Many are treated with palliative rather than corrective surgical procedures..$^{24,25} \mathrm{We}$ evaluated the role of hypothermic cardiopulmonary bypass and circulatory arrest (HCA) in conjunction with anatomic corrective surgical techniques in the management of such cases.

\section{Patients and Methods \\ Patients}

From June 1993 to November 1999, a total of 13 adult patients (mean age 38 years, range 20-63 years) with aortic coarctation and coexisting abnormalities of the aorta and the left subclavian artery 


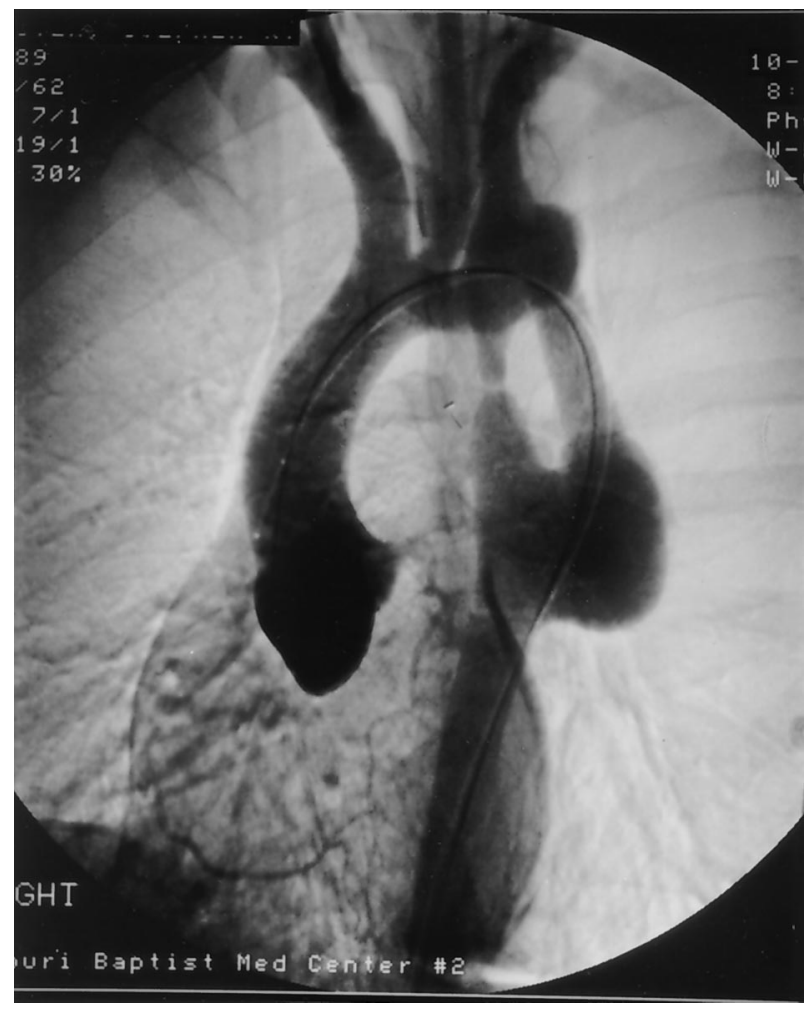

Figure 1. Aortogram from patient with previous coarctation repair with aorta-to-aorta bypass graft (patient 11). Proximal and distal anastomotic pseudoaneurysms have formed.

were treated (Table 1). Six of these patients had undergone previous surgical repair. Five of the 6 had pseudoaneurysms develop after bypass grafting (patients 1, 6, and 11; Figure 1) or patch aortoplasty (patients 2 and 12; Figure 2). These were detected a mean of 21 years (range 13-44 years) after the initial operation. Four of these 5 patients had no symptoms (patients 1, 2, 6, and 11), and 1 had rupture of the aorta at the operative site (patient 12). The sixth patient (patient 3) had recurrent coarctation from fibrous obliteration of a $10-\mathrm{mm}$ bypass graft inserted 15 years previously, resulting in hypertension, exertional dyspnea, and claudication. The remaining 7 patients had aneurysms of the left subclavian artery ( $\mathrm{n}=5$ patients) (Figure 3 ), the ascending aorta and arch (patient 10), or stenosis of the left subclavian artery (patient 13; Figure 4) in combination with moderate or severe coarctation. One patient (patient 5) had anomalous origin of the right subclavian artery as the fourth branch of the aortic arch. All but 5 patients (patients 2, 5, 6, 8, and 9) had hypertension. The mean New York Heart Association functional class was II.

\section{Operative Technique}

Hemodynamic monitoring included right radial artery cannulation for the monitoring of arterial pressure and placement of a pulmonary artery catheter. Electroencephalographic monitoring was used. Two lines for arterial perfusion were connected to the main arterial line of the pump-oxygenator to provide control of selective flow (proximal and distal) as needed with an occluder and a

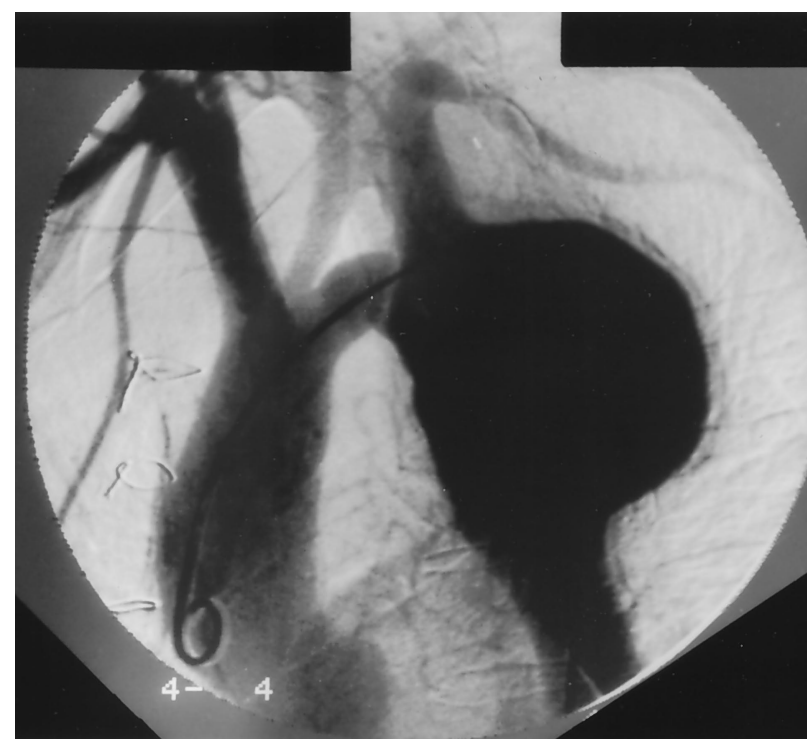

Figure 2. Aortogram from patient with previous coarctation repair with patch aortoplasty (patient 2). Large pseudoaneurysm has formed.

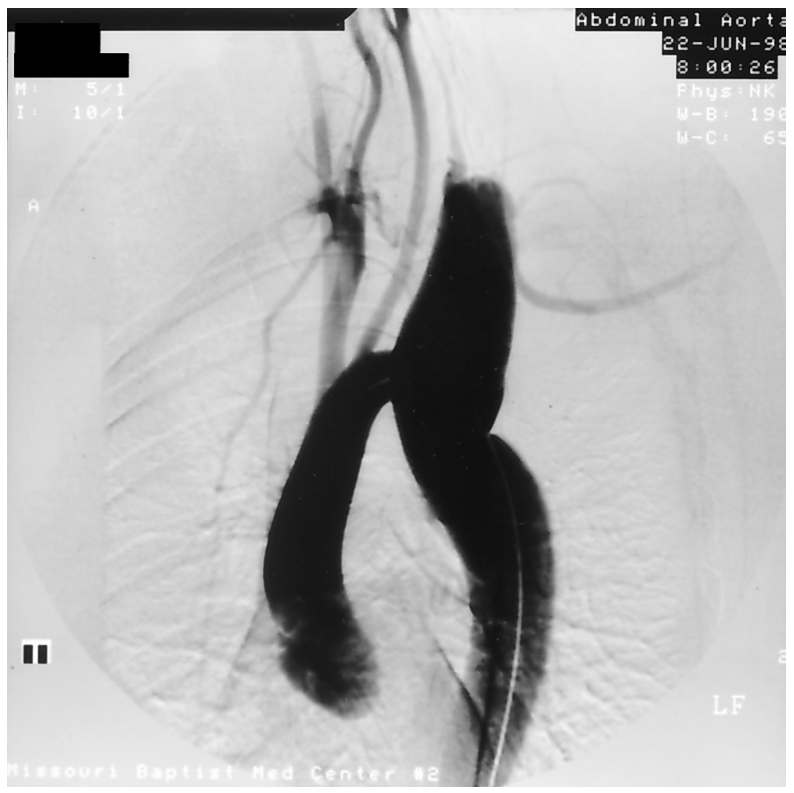

Figure 3. Aortogram from patient with coarctation between left subclavian and carotid arteries, aneurysm of proximal descending aorta, and aneurysm of proximal left subclavian artery (patient 8).

flowmeter (HT 109; Transonic Systems, Inc, Ithaca, NY). Provision was also made for retrograde venous perfusion by placing a connecting tube between the arterial and the venous line at the cardiopulmonary bypass circuit. Clamping of the arterial line and opening of the connecting tube between the venous and the arterial lines allowed retrograde venous perfusion. After endotracheal in- 


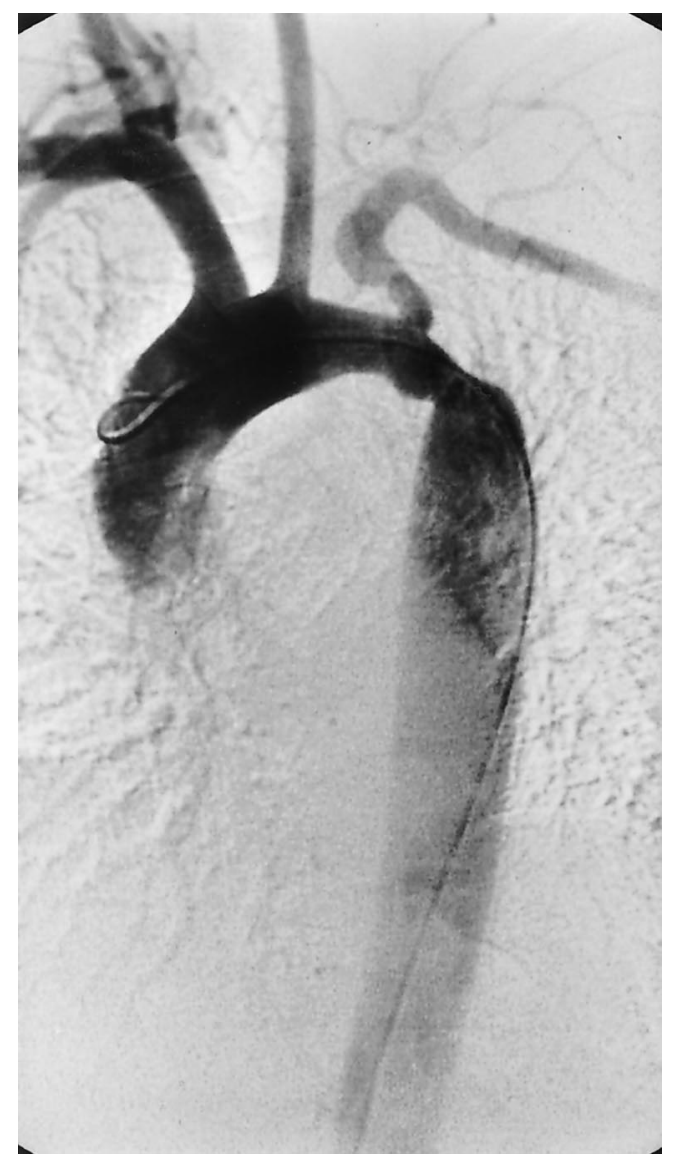

Figure 4. Aortogram from patient with coarctation and stenosis of left subclavian artery (patient 13).

tubation with a double-lumen tube to permit deflation of the left lung, the patient was positioned on the operating table in a right lateral decubitus position with the hips turned to the left at a $45^{\circ}$ angle.

A standard posterolateral thoracotomy incision was made through the fourth intercostal space. Simultaneously, the left common femoral artery and vein were isolated through an oblique incision in the skin crease of the groin. After opening of the chest, heparin was administered to achieve and maintain an activated clotting time longer than 500 seconds. A long cannula (28F to $34 \mathrm{~F}$ ) was inserted through the left common femoral vein and was positioned in the right atrium under transesophageal echocardiographic guidance. The femoral artery was cannulated with a $20 \mathrm{~F}$ or $22 \mathrm{~F}$ cannula. Cardiopulmonary bypass was established, and cooling was immediately initiated. During the period of cooling, the proximal descending thoracic aorta and the area of the distal aortic arch were carefully mobilized. The left recurrent laryngeal nerve was identified and protected. If an aneurysm was present, the adventitia was not dissected until after circulatory arrest had been established. Methylprednisolone $(7 \mathrm{mg} / \mathrm{kg}$ ) and thiopental (10 to $15 \mathrm{mg} / \mathrm{kg}$ ) were given during cooling. If the heart became distended or if a significant increase in pulmonary artery pressure occurred after the heart fibrillated, a venting catheter was inserted through either the left inferior pulmonary vein or the apex of the left ventricle. Venting was used in 5 of 13 cases. Cooling was continued until electroencephalographic silence was achieved, usually at a nasopharyngeal temperature of $15^{\circ} \mathrm{C}$ to $17^{\circ} \mathrm{C}$. At this temperature, adequate myocardial protection is achieved without the use of cardioplegia. Ice packs were placed around the patient's head, the head was placed in a dependent position, the venous cannula was occluded, the intracardiac vent was occluded, and 1000 to $1500 \mathrm{~mL}$ of blood was drained into the venous reservoir. At this point a clamp was placed on the mid-descending thoracic aorta to minimize blood loss into the operative field.

During the period of HCA, the involved segment of the aorta was incised, the anatomy was carefully examined, and the orifices of the arch branches were identified. The aorta was usually transected circumferentially just distal to the origin of the left subclavian artery. If the subclavian artery was involved with aneurysmal disease or had been used previously as the anastomotic site for a bypass conduit, the aorta was transected between the origins of the left common carotid artery and the left subclavian artery, and the abnormal segment of the subclavian artery was resected. Distally, the aorta was transected in a beveled fashion below the level of the coarctation, to preserve patent intercostal arteries. A collagen-impregnated woven polyester aortic graft (Hemashield; Meadox Medicals, Inc, Oakland, NJ) was sutured end to end to the proximal aorta with a continuous 3-0 or 4-0 polypropylene suture buttressed with a strip of felt. As this suture line was completed, cold blood $\left(10^{\circ} \mathrm{C}-12^{\circ} \mathrm{C}\right)$ from the pump-oxygenator was infused retrogradely into the venous circulation to assist in the evacuation of air from the upper circulation and from the graft.

The graft was clamped adjacent to the proximal anastomosis, and the distal anastomosis was constructed in a similar manner during the period of HCA. As this suture line was being completed, arterial perfusion was reestablished through the femoral artery. The clamp on the descending aorta was removed, and air was evacuated from the graft with an 18-gauge needle. Adequate deairing of the proximal aorta could also be achieved without the use of retrograde venous perfusion, simply by perfusing the femoral arterial cannula slowly while a clamp was applied on the distal aorta. With this maneuver, the proximal aorta was filled with blood supplied through collateral circulation. The clamp on the graft was removed, and cardiopulmonary bypass and rewarming were initiated. Cardiopulmonary bypass was discontinued when the bladder temperature reached $35^{\circ} \mathrm{C}$.

When reconstruction of the left subclavian artery was needed ( $\mathrm{n}=7$ patients: $4,5,6,7,8,9$, and 13 ), it was usually performed during the period of rewarming. A 10- to 14-mm graft (Hemashield; Meadox Medicals) was anastomosed end to end to the distal subclavian artery and end to side to the aortic graft with the use of a partially occluding clamp. Occasionally, when extensive resection of the left subclavian artery was necessary, the anastomosis of the graft to the subclavian artery was performed during the period of HCA.

Modifications of this perfusion strategy were sometimes required. Perfusion of the proximal aorta was expected to be necessary on occasion. One patient with a previous aortic valvotomy and significant aortic regurgitation (patient 6) had distention of the heart develop during the period of cooling and hypothermic fibrillation, despite the use of a left ventricular vent. The vent was removed, and an arterial perfusion cannula was inserted through 
the apex of the heart and positioned into the aortic root under transesophageal echocardiographic guidance. Thirty-five percent of the total arterial flow was directed through the proximal arterial line, and $65 \%$ was directed through the distal line. This maneuver corrected the problem of heart distention by minimizing the amount of aortic regurgitation with placement of the cannula through the center of the aortic valve. Patient 12 had complete disruption of a patch aortoplasty suture line and a large false aneurysm that required emergency operation. In that case it was considered unsafe to use distal perfusion, for fear of insufficient perfusion of the heart and the brain. Instead, the left axillary artery was perfused through a 10-mm polyester graft and was used as the only site for arterial return. At the conclusion of the operation, the graft was transected and ligated close to the axillary artery.

Intercostal arteries below the level of the coarctation were preserved in most cases by beveling the distal aorta-to-graft anastomosis. No intercostal arteries were reimplanted separately. Several upper thoracic intercostal arteries were sacrificed (patients 1, $2,5,6$, and 8). A large chest wall collateral to the aorta emptying distal to the area of the coarctation was present in 1 case (patient $10)$, and this was preserved.

\section{Results}

There were no in-hospital or late deaths (mean follow-up 23 months, range 4 months to 7 years). All patients were extubated within 24 hours after the operation. No patient required reoperation for bleeding. One patient with preoperative paralysis of the left vocal cord (patient 12) had pneumonia develop and required reintubation and assisted ventilation for 5 days. Patient 7 had development of atelectasis of the left lung as the result of a mucous plug and was treated successfully with bronchoscopy. Patient 9 had pneumonia that subsided with antibiotics. No patient had brain or spinal cord ischemic injury, recurrent nerve injury, chylothorax, myocardial failure, respiratory failure, or elevation of the serum creatinine level above baseline levels. Patient 12 had empyema and a perigraft abscess develop and was treated with topical and systemic antibiotics. At last followup, at 18 postoperative months, there was no evidence of infection. The mean perioperative transfusion requirement was 1.9 units of packed red blood cells (range 0-10 units). Six patients received no blood products. Three patients (patients 1, 9, and 12) received fresh-frozen plasma during the perioperative period (average 1.2 units), and the same patients also received concentrated platelets. No patient received cryoprecipitate or aprotinin. The mean postoperative stay in the intensive care unit was 3 days (range 1-8 days), and the mean postoperative hospital stay was 8.3 days (range 5-20 days).

Perfusion data are summarized as follows: mean duration of HCA, 44 minutes (range 33-54 minutes); mean duration of cardiopulmonary bypass, excluding duration of HCA, 92 minutes (range 65-145 minutes); and mean duration of hypothermic fibrillation, 80 minutes (range 61-93 minutes). The duration of HCA in this group of patients also repre- sented the duration of lower body ischemia, which is synonymous with spinal cord ischemia. Retrograde venous perfusion through the venous cannula was used in the last 6 cases to assist with evacuation of air from the upper circulation and from the graft (duration range 3-10 minutes).

Among the 8 patients with preoperative hypertension, 4 were discharged from the hospital requiring no antihypertensive medications (patients 1, 3, 11, and 12). Two (patients 4 and 10) required single-drug antihypertensive therapy, and 2 (patients 7 and 13) required two drugs.

During the follow-up period there has been no evidence for recurrent coarctation. No patients have required reoperation on the aorta.

\section{Discussion}

Complex forms of primary or recurrent coarctation associated with hypoplasia of the aortic arch or aneurysmal dilatation of the left subclavian artery represent a surgical challenge. Patch repair of coarctation of the aorta is a well-established technique that involves minimal mobilization of the aorta and the collateral branches. There is, however, a well-documented risk of aneurysm formation that is related to the use of prosthetic material and is probably unrelated to resection of the intimal ridge at the site of the stenosis. The incidence of late aneurysm formation after patch graft aortoplasty ranges from $27 \%$ to $89 \%$ and appears to be highest for repairs performed during the patient's adult life.3,10,12,26 Aneurysm formation has also been reported after bypass grafting for long aortic coarctation and after subclavian flap aortoplasty. ${ }^{11,13,24}$ Reoperation for aneurysms related to previous patch graft aortoplasty carries a mortality as great as $13.8 \%$ and significant morbidity, including recurrent nerve paralysis and bleeding complications.9,12 Patients not reoperated on almost uniformly die of rupture of the aneurysm 7 to 15 years after coarctation repair. ${ }^{12}$ Because of the high risk involved, extra-anatomic surgical approaches have been advocated for complex forms of primary coarctation and for complications related to previous surgical repair. ${ }^{24,25}$

Kieffer and colleagues ${ }^{18}$ treated 17 patients with aneurysmal disease of aberrant subclavian arteries. Seven of these patients had associated abnormalities (usually aneurysms) of the thoracic aorta. Cardiopulmonary bypass with HCA was used electively in one patient with good postoperative outcome. In 2 other cases the need for HCA arose because of technical difficulties during the operation. One of these patients died of heart failure on the first postoperative day. Three other patients in whom HCA was not used died of postoperative complications. Two of these patients had paraplegia develop. Overall, in that series of 17 patients the mortality was $23.5 \%$, and the incidence of paraplegia was $12 \%$.

Lange and coworkers ${ }^{27}$ used HCA in 17 adolescent patients with recurrent coarctation and persistent hypoplasia of 
the aortic arch, with excellent results. They used graft interposition in 14 cases and end-to-end primary anastomosis in 3 cases. In contrast, among 11 patients operated on by the same authors with simple aortic crossclamping, 2 required early reoperation because of inadequate repair. In this report of 28 operations (26 patients), there was no associated aneurysmal disease of the aorta or the subclavian arteries.

In our series, we treated 13 adult patients with complicated forms of coarctation, 6 of whom had undergone previous surgical therapy and 7 of whom had undergone no previous surgery but had coexisting arterial abnormalities. Successful precise anatomic repair was achieved in all cases with the technique of hypothermic cardiopulmonary bypass and HCA. There were no in-hospital or late deaths, and none of the patients had a central neurologic deficit.

In cases of complex forms of coarctation, with or without coexisting arterial abnormalities, elective use of HCA is preferred to unplanned application of the method when technical difficulties arise. In the latter situation, intraoperative complications such as bleeding may necessitate emergency use of HCA. Elective implementation of HCA reduces the prevalence of these complications and avoids the perils of emergency cannulation techniques. Furthermore the aorta, even when not aneurysmal, often has pathologic characteristics at the level of the arch and the proximal descending aorta, making the application of clamps not only technically difficult but often hazardous.

Exposure of aneurysmal subclavian arteries at the level of the aortic arch, particularly when accompanied by complex forms of aortic aneurysmal disease, can be technically challenging. Elective use of HCA provides protection from intraoperative hemorrhage. In our series there were no bleeding complications, and the requirements for blood product transfusion (average of 1.9 units of packed red blood cells) were reasonable. Exposure of the middle and distal transverse arch is occasionally necessary when recurrent coarctation in these segments of the aorta is an associated anatomic feature. Patch enlargement of the undersurface of the arch is readily accomplished with this technique.

The risk of spinal cord ischemic injury in patients with recoarctation or with aneurysmal disease of the aorta or the subclavian arteries is substantial when no distal perfusion techniques are used. In the presence of complicated forms of aneurysm at the site of previous coarctation repairs, application of clamps on the aorta may not be possible. In such cases adequate protection of the spinal cord can be achieved only if HCA is used. In our series no patient had evidence of spinal cord ischemic injury.

The technique of hypothermic cardiopulmonary bypass with HCA has several advantages when applied to adult patients with complex forms of coarctation and coexisting arterial abnormalities. It facilitates adequate exposure of the structures involved, avoids placement of clamps on fragile tissue, and provides adequate protection of the brain, the spinal cord, and other organs. We conclude that use of this technique is warranted for these challenging cases.

\section{References}

1. McGrath LB, Gonzalez-Lavin L, Amini SB, Graf D. Late events following repair of aortic coarctation with resection and end-to-end anastomosis: a twenty-five-year experience. Heart Vessels. 1990;5: 93-7.

2. Jahangiri M, Shinebourne EA, Zurakowski D, Rigby ML, Redington AN, Lincoln C. Subclavian flap angioplasty: does the arch look after itself? J Thorac Cardiovasc Surg. 2000;120:224-9.

3. Clarkson PM, Brandt P., Barratt-Boyes BG, Rutherford JD, Kerr AR, Neutze JM. Prosthetic repair of coarctation of the aorta with particular reference to Dacron onlay patch grafts and late aneurysm formation. Am J Cardiol. 1985;56:342-6.

4. Owens WA, Tolan MJ, Cleland J. Late results of patch repair of coarctation of the aorta in adults using autogenous arterial wall. Ann Thorac Surg. 1997;64:1072-4.

5. Elkerdany A, Hassouna A, Elsayegh T, Azab S, Bassiouni M. Left subclavian-aortic bypass grafting in primary isolated adult coarctation. Cardiovasc Surg. 1999;7:351-4.

6. Aris A, Subirana MT, Ferres P, Torner-Soler M. Repair of aortic coarctation in patients more than 50 years of age. Ann Thorac Surg. 1999;67:1376-9.

7. Fawzy ME, Sivanandam V, Galal O, Dunn B, Patel A, Rifai A, et al. One- to ten-year follow-up results of balloon angioplasty of native coarctation of the aorta in adolescents and adults. J Am Coll Cardiol. 1997; 15:1542-6.

8. Ebeid MR, Prieto LR, Latson LA. Use of balloon-expandable stents for coarctation of the aorta: initial results and intermediate-term follow-up. J Am Coll Cardiol. 1997;30:1847-52.

9. Ala-Kulju K, Keikkinen L. Aneurysms after patch graft aortoplasty for coarctation of the aorta: long-term results of surgical management. Ann Thorac Surg. 1989;47:853-6.

10. Aebert H, Laas J, Bednarski P, Koch U, Prokop M, Borst HG. High incidence of aneurysm formation following patch plasty repair of coarctation. Eur J Cardiothorac Surg. 1993;7:200-4.

11. Fujita T, Fukushima N, Taketani S, Kadoba K, Kagisaki K, Imagawa $\mathrm{H}$, et al. Late true aneurysm after bypass grafting for long aortic coarctation. Ann Thorac Surg. 1996;62:1511-3.

12. Knyshov GV, Sitar LL, Glagola MD, Atamanyuk MY. Aortic aneurysms at the site of the repair of coarctation of the aorta: a review of 48 patients. Ann Thorac Surg. 1996;61:935-9.

13. Kino K, Sano S, Sugawara E, Kohmoto T, Kamada M. Late aneurysm after subclavian flap aortoplasty for coarctation of the aorta. Ann Thorac Surg. 1996;61:1262-4.

14. Yetman AT, Nykanen D, McCrindle BW, Sunnegardh J, Adatia I, Freedom RM, et al. Balloon angioplasty of recurrent coarctation: a 12-year review. J Am Coll Cardiol. 1997;30:811-6.

15. Ralph-Edwards AC, Williams WG, Coles JC, Rebeyka IM, Trusler GA, Freedom RM. Reoperation for recurrent aortic coarctation. Ann Thorac Surg. 1995;60:1303-7.

16. Sakopoulos AG, Hahn TL, Turrentine M, Brown JW. Recurrent aortic coarctation: is surgical repair still the gold standard? J Thorac Cardiovasc Surg. 1998;116:560-5.

17. Bouchart F, Dubar A, Tabley A, Litzler PY, Haas-Hubscher C, Redonnet $\mathrm{M}$, et al. Coarctation of the aorta in adults: surgical results and long-term follow-up. Ann Thorac Surg. 2000;70:1483-8.

18. Kieffer E, Bahnini A, Koskas F. Aberrant subclavian artery: surgical treatment in thirty-three adult patients. J Vasc Surg. 1994;19:100-9.

19. Argotte AF, Giron F, Bilfinger TV. Bilateral subclavian artery aneurysms with pseudocoarctation of the aorta. J Cardiovasc Surg. 1998; 39:747-50.

20. Beekman RH, Rocchini AP, Behrend DM, Rosenthal A. Reoperation for coarctation of the aorta. Am J Cardiol. 1981;48:1108-14.

21. Fisher M, Sacco RL. Prophylactic neuroprotection for cerebral ischemia. Stroke. 1994;25:1075-80. 
22. Pennington DG, Liberthson RR, Jacobs M, Scully H, Goldblatt A, Daggett WM. Critical review of experience with surgical repair of coarctation of the aorta. J Thorac Cardiovasc Surg. 1979;77:217-29.

23. Sweeney MS, Walker WE, Duncan JM, Hallman GL, Livesay JJ, Cooley DA. Reoperation for aortic coarctation: techniques, results, and indications for various approaches. Ann Thorac Surg. 1985;40: 46-9.

24. Grinda JM, Mace L, Dervanian P, Folliguet TA, Neveux JY. Bypass graft for complex forms of isthmic aortic coarctation in adults. Ann Thorac Surg. 1995;60:1299-302.
25. Caspi J, Ilbawi MN, Milo S, Bar-El Y, Roberson DA, Thilenius OG, et al. Alternative techniques for surgical management of recoarctation. Eur J Cardiothorac Surg. 1997;12:116-9.

26. Ala-Kulju K, Jarvinen A, Maamies T, Mattila S, Merikallio E. Late aneurysms after patch aortoplasty for coarctation of the aorta in adults. Thorac Cardiovasc Surg. 1983;31:301-5.

27. Lange R, Thielmann M, Schmidt KG, Bauernschmitt R, Jakob H, Hasper B, et al. Spinal cord protection using hypothermic cardiocirculatory arrest in extended repair of recoarctation and persistent hypoplastic aortic arch. Eur J Cardiothorac Surg. 1997;11:697-702.

\section{Timely}

The Journal of Thoracic and Cardiovascular Surgery delivers the information you need now. Articles usually appear within four months of acceptance. 